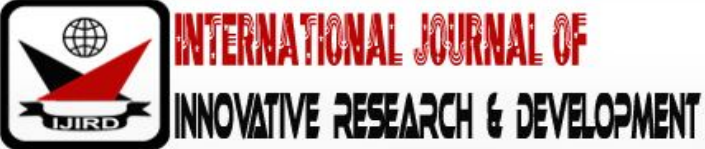

ISSN 2278 - 0211 (Online)

\section{Role of Stakeholders Participation on National Budget Oversight in Kenya}

Anne Mwaura
Ph.D. Candidate, Department of Leadership and Governance,
Jommo Kenyatta University of Agriculture and Technology, Kenya
Dr. Gladys Rotich
Associate Chair, CES, Jommo Kenyatta University of Agriculture and Technology, Kenya
Dr. Gerald Liguyani Majany
Adjunct Lecturer, Jomo Kenyatta University of Agriculture and Technology, Kenya

\begin{abstract}
:
Stakeholder participation is a social economic concept reputably adopted by most modern democracies world over. Stakeholder participation is founded by constitutional mandates globally. it is a major framework on whose basis democratic governance is enhanced. Scholars consider stakeholder participation to be a twofold aspect of effective governance which firstly includes the quantity of stakeholder actors and secondly the extent to which stakeholders take advantage of opportunities to participate in governance processes (Rabinowitz, 2016). Stakeholder participation is viewed as a check and balance mechanism for accountability, transparency and integrity assurances. Notwithstanding, political scientists, governance scholars continue to raise questions in regard to whether global governance has democratic legitimacy. Cross sections of researchers have alluded to the fact that this question can partially be addressed though effective stakeholder participation. This paper seeks to analyze the role of stakeholder's participation on national budget oversight in Kenya.
\end{abstract}

Keywords; Stakeholder participation, National budget oversight, accountability, transparency, service delivery

\section{Introduction}

In most developing countries, public budgeting is still considered as a state secret, and the process is controlled exclusively by the executive (Kim et al., 2016). Moreover, modern economies' budgets are very complex, allowing practices that aim to hide the real budget balance. Politicians have little incentives to disclose simple, clear, and transparent budgets. Accordingly, accountability mechanisms are required to verify that governments meet their duties. Budget transparency can be one of these mechanisms. The $21^{\text {st }}$ century has been characterized by increased competition and a dynamic business environment. A critical component of this is the organizations stakeholders whose vigilance and interest has increased in recent times due to enlargement of democratic rights, increased legal freedom and the enablement of advances in information communication technology

\subsection{Background of the Study}

This paper infers that Stakeholder participation is a central to building awareness of the importance of Governments as having a moral obligation to their citizens to be transparent about their handling of tax-payers' money (Willmont, 2017). Government budgets represent financial plans which specify how public resources are going to be used to meet policy goals. It currently poised as the changing context within which good global governance is practiced. This emerging context gives prominence to the critical aspects of transparency, accountability, sustainability and service delivery (Koontz \& Newig, 2014

The budget plays a central role in the lives of every citizen. Citizens, especially poor and low-income ones, are the primary beneficiaries of government programs financed through the budget. It is therefore essential that citizens understand government budgets, and have access to information that will allow them to hold the government accountable for the use of public funds. Unfortunately, citizens legislatures, and the media have been traditionally excluded from budget decision-making and monitoring.

\subsubsection{Global Perspective of Stakeholder Participation}

The global model of stakeholder participation aims to entrench political representation and accountability which are said to be means of advancing sustainable human development. Societies with strong, democratic institutions empower people to influence their governments to prioritize national development that is equitable and sustainable. In true democratic governance, people can demand better policies, express grievances, hold leaders to account as well as 
seek justice from abuse (Holmes. 2011). Although it can be difficult, complicated, time-consuming and sometimes impossible to promote stakeholders participation such as citizens in decision making, consensus-based decisions are often more legitimate and widely accepted than not. This is known as the 'slow-fast' method of decision making, because consensus-building can be laboriously slow in the initial stages but once there is a broad agreement policy implementation can be fast and more effective (Kahneman \& Daniel,2011).

Stakeholder participation is an important element of democracy because 'rule by the people' is the underlying and founding principle of democracy. Thus, involving people in making decisions that concern their lives is a distinguishing feature of developed democratic societies around the world. Participatory democracy requires active and meaningful engagement of citizens embedded on strong institutional arrangements sometimes requiring reorganization and change of government agencies' culture (Reed, 2008).

In recent times, a redefining of the concept of global leadership has been put forward emphasizing the need for international cooperation among governments, civil society and the private sector for collective global good which seeks to hold citizens responsible and accountable for their actions (Moon, 2015). The foundation of this thinking is the need to anchor stakeholder participation in governance structure for effectual outcomes across the globe

\subsubsection{Regional Perspective of Stakeholder Participation}

In Africa, for more than 40 years, different stakeholders have partnered to support the development and implementation of national budget since independence (Woolum, 2011).countries such as Nigeria, Ghana, Sierra Leone, Zaire, and the Central African Republic, the have attempted to promoting participatory democracy as an important principle in the governance of public affairs has been an important theme in regional debates (Palazzo, 2016). Stakeholder participation is said to build people's abilities to hold authorities to account for the implementation of decisions and actions that have been agreed upon.

\subsubsection{Local Perspective of Stakeholder Participation}

Kenya promulgated her new Constitution in 2010 which is arguably one of the most progressive constitutions in the world (Government Press,2010). The document in Article 10 enshrines citizen participation a central part of Kenya's governance system. Further, the constitution in Article 174(c) provides that the object of devolution is aimed at enhancing the participation of people in the exercise of the powers of the State and in making decisions which affect them. The centrality of public participation cannot therefore be over-emphasized beyond the constitutional thresholds and provisions. The concept of stakeholder participation is not new to Kenya though; the country has had a significantly long history of direct participation in government though the formations of devolved funds such as the Constituency Development Fund (CDF) and Local Authority Service Delivery Action Plans (LASDAP).

There has been a good attempt to consolidate respect and institutionalization of the sovereignty of Kenyans in all processes of governance. However, securing and concretizing participatory democracy has dominated discourses on governance in Kenya for a long time(Kanyinga 2014). The struggle for political liberalization from the late 1980s was particularly informed by the need to place primacy on people's participation in decision-making, because the single party rule often tended to impose decisions that promoted parochial and individual political interests rather than the public good.Despite these efforts, the protracted struggles for reforms have not translated into concrete participatory democratic practices especially for a devolved system of government where people effectively participate in the governance of their units.

\subsubsection{Stakeholder Participation and Budget Oversight}

Stakeholder participation has a role in development policymaking, budget oversight and its implementation. It appeals to policymakers and scientists because it can be used to achieve the triple goals of good governance, democracy and sustainable development. However, critics argue that there are weaknesses in its application such as: over representation of some groups; exclusion of some groups; likelihood of conflict among participants; time intensive and expensive; poor procedures for taking diverse views into account; and the diversity of intensity of involving stakeholders in decision making processes referred to as the ladder of stakeholder participation. Stakeholder participation in government has become a strategy advocated for better development and good governance, drawing wide attention from public administration scholars and practitioners (Nabatchi, Ertinger \& Leighninger, 2015.

Budget oversight includes a number of activities that aim to measure whether public resources have been used appropriately, effectively, and efficiently. At the end of the fiscal year, the executive branch should report its financial activities to the legislature and the public, as well as to an independent and professional supreme audit institution (SAI). The number and nature of stakeholders will vary with the nature of budget being made, thus would make sense to carry out the review of identification throughout the budget making process (Willmont, 2017). Accordingly, the role of budget transparency has increasingly attracted attention from governments and international organizations as a way to prevent failures in the future and give credibility to economic policies. This concern has triggered the development of budget transparency international standards such as the "Code of Good Practices on Fiscal Transparency" (published by IMF in 1998 and updated in 2007) or the "Best Practices for Budget Transparency" (published by the OECD in 2001).

Stakeholders improves the quality and accuracy of budgets (Sierra-Garcia, Zorio-Grima \& Garcia-Benau, 2015). Thus, if the budgeted values are correct, more achievable, better estimated, the entity may register a reduction of the budget deviations (Finch, 2015). However, in order to make budgets be perceived as fair, participation is not the only thing considered to be important. It is important for stakeholders to also receive an explanation if their views and opinions are not taken into account, and they cannot influence the final budget (Bryer, 2014). 
Though the budget is accompanied annually with fantastic rhetoric detailing messages of hope for the masses, budgets at all levels have not had the desired impact in the lives of the people. As a result, the majority of the citizenry continue to groan under the weight of overwhelming poverty. Stakeholder participation and accountability in the budgeting process is low or nonexistent. Budgets are important government documents, crucial to a nation's development (Box, 2015). Efforts must therefore be stepped up to ensure that the process is participatory and effective in translating government plans into tangible and long term development benefits for the people. Until the budget is representative of the peoples' aspirations, it will continue to remain just another government document on the shelf without real benefit in the lives of the poor majority.

\subsection{Research Problem}

While it seems apparent that citizen participation can only serve to inform, and thus improve, the operation of government, turnout at public hearings and other forums for communication is not always high. Kenyans have deep and longstanding concerns about the ways in which resources have been distributed throughout the country (Finch \& Omolo, 2015). Many regions and communities feel that they have been excluded by a strong central regime. Stakeholder participation is in part about aligning the needs and demands of the public more closely with the choices of government officials. International financial institutions and donors have raised their expectations and concerns over economic and financial accountability from African countries. Kenya is not an exception. The economic objectives of public accountability sought by the World Bank, for example, include congruence between public policy and actual implementation as well as efficient allocation and use of public resources. (Migal, 2010). However, there is lack of stakeholders' participation, poor governance and low capacity of implementing strategies. This suggests that stakeholder participation must occur at the formulation and approval stages of the budget, when priorities are being set. At this stage, stakeholder participation can enhance decision making by bringing information about public needs to the attention of policymakers as they prioritize their spending (Finch, 2015).

This can lead to more equitable distribution of resources. Stakeholder participation in the development of budgets and the consideration of human nature and its effects on entities activities can generate amazing benefits. People are subjective, biased, emotional, have views, opinions and feelings (Finch, 2015). For an efficient conduct and fulfillment of budgeted targets, the entity management must "attract" stakeholders on their side.

Stakeholders need to be involved at each stage of the budget planning process. Their knowledge of local social, economic, political, and ecological conditions provides the yardstick against which proposed solutions must be measured. Also, the goals, problems, and remediation strategies generated by stakeholders define what's desirable and achievable (Finch, 2015). Weaving stakeholder input, legal requirements, and resource protection strategies into an integrated tapestry for managing resources. Involving stakeholders in the budgeting process and enabling them to influence the final budgets, makes them develop a positive attitude towards superior and budgets (Purvis, Zagenczyk \& McCray, 2015). The fact that their superiors involves them in the decisions making process and the fact that they are taking into account their views and knowledge, leads stakeholders to assess leadership as fair and trust worthy, appreciating the transparency in the decision making process. Thus, stakeholders become more attached to the entity's goals (organizational commitment). Budgetary participation creates a bond of trust between stakeholders and superiors requiring collaboration and communication between them also, because the goals set by budgets are the result of negotiations and stakeholders participate in their setting. They perceive budgets and budgeting procedures as achievable and fair (Finch \&Omolo, 2015). It is in this backdrop that the paper deciphers to investigate The Role of stakeholders participation on national budget oversight in Kenya.

\subsection{Research Objectives}

\subsubsection{General Objective}

The General objective of this study was to assess the role of stakeholders' participation on national budget oversight in Kenya.

\subsubsection{Specific Objectives}

The specific objectives of this study were:

- Determine the level of civil society organizations participation on national budget oversight in Kenya.

- Evaluate the efficacy of funding agencies participation on national budget oversight in Kenya

\subsection{Significance of the Study}

This paper may be beneficial to the following

\subsubsection{County Governments and Policy Makers}

The study will provide information for policy makers in formulating strategies, policies programs, and projects and form the basis of assessment of national budget oversight in Kenya. It will inform Public financial institutions of the need to be able to manage public resources and conduct public affairs in a manner that submits to management of public finances and as stipulated by relevant statutes. 


\subsubsection{Scholars and Academicians}

The study shall contribute to further knowledge in understanding of the influence of Stakeholder Participation onnational budget oversight in Kenya within the setup of Counties in Kenya. Future researchers could refer to this paper todevelop their research inquiries and also to aid in conceptualization of their studies. Others can also replicate this study for further research inquiry and work. Further, given the nascent availability of literature on the causal relationship between stakeholders' participationand on national budget oversight in Kenya, it is expected that the study will provide a good source of current reference on the subject.

\subsubsection{Scope of the Study}

The research paper shall assess the Influence of stakeholder participation on on national budget oversight in Kenya.

\section{Literature Review}

\subsection{Introduction}

The section provides an extensive literature and research related to the role of stakeholder participation on national budget oversight in Kenya. This literature review summarizes a diverse spectrum of views about management practices. The chapter is thus structured into theoretical, conceptual and empirical review. The study also presents the knowledge gap the chapter seeks to fulfill.

\subsection{Theoretical Review}

This research paper is grounded on hereunder theories and models

\subsubsection{The Functionalist Theory}

Functionalist perspective is based largely on the works of Emile Durkheim, According to functionalism, society is a system of interconnected parts that work together in harmony to maintain a state of balance and social equilibrium for the whole Functionalism interprets each part of society in terms of how it contributes to the stability of the whole society. Society is more than the sum of its parts; rather, each part of society is functional for the stability of the whole (Taylor\&Gooby, 2009).

Durkheim actually envisioned society as an organism, and just like within an organism, each component plays a necessary part, but none can function alone, and one experiences a crisis or fails, other parts must adapt to fill the void in some way. Within functionalist theory, the different parts of society are primarily composed of social institutions, each of which is designed to fill different needs, and each of which has particular consequences for the form and shape of society. The parts all depend on each other. The core institutions defined by sociology and which are important to understand for this theory includes: family, government, economy, media, education, and religion (Crossman, 2017).

The functionalist theory argues that every piece of society is interdependent and contributes to the functioning of society as a whole unit. If the functionalist theory is correct and everyone understands how each segment functions within the unit of society, then it breeds stability, prosperity, order and productivity. If a society is a functionalist society and the theory fails, then the society is either doomed to fall into chaos or the members of the society must quickly adapt to regain the order, stability and productivity of the society (Outhwaite, 2008).

From the functionalist perspective, if all goes well, the parts of society produce order, stability, and productivity. If all does not go well, the parts of society then must adapt to produce new forms of order, stability, and productivity. Functionalism emphasizes the consensus and order that exist in society, focusing on social stability and shared public values. Durkheim's interest was in how social order could be possible, and how society maintains stability (Christensen \& Krogman, 2012). It is in view of the above that functionalist perspective provides tangible approaches and suggestions on which basis this study shall examine the influence of stakeholder participation onnational budget oversight in Kenya.

\subsubsection{Stakeholder Participation Theory}

Stakeholder theory was introduced by Edward Freeman in 1988. The stakeholder theory is a theory of organizational management and business ethics that addresses morals and values in managing an organization. The complex and dynamic nature of problems requires flexible and transparent decision-making that embraces a diversity of knowledge and values. For this reason, stakeholder participation in decision-making has been increasingly sought and embedded into national and international policy.

In the traditional view of a company, the shareholder view, only the owners or shareholders of the company are important, and the company has a binding fiduciary duty to put their needs first, to increase value for them. Stakeholder theory instead argues that there are other parties involved, including employees, customers, suppliers, financiers, communities, governmental bodies, political groups, trade associations, and trade unions Freeman, R. Edward (1984).Even competitors are sometimes counted as stakeholders. Their status being derived from their capacity to affect the firm and its stakeholders. The nature of what constitutes a stakeholder is highly contested (Miles, 2012).

The stakeholder view of strategy integrates both a resource-based view and a market-based view, and adds a socio-political level. One common version of stakeholder theory seeks to define the specific stakeholders of a company (the normative theory of stakeholder identification) and then examine the conditions under which managers treat these parties as stakeholders (the descriptive theory of stakeholder salience Phillips, Robert (2003). 
The theory does not imply that all stakeholders (however they may be identified) should be equally involved in all processes and decisions he stakeholder theory differs from these and other "theories of the firm" in fundamental ways(Brenner \& Cochran, 1991),. The stakeholder theory is intended both to explain and to guide the structure and operation of the established corporation (the "going concern" in John R. Commons' famous phrase). Toward that end it views the corporation as an organizational entity through which numerous and diverse participants accomplish multiple, and not always entirely congruent, purposes. The stakeholder theory is general and comprehensive, but it is not empty; it goes well beyond the descriptive observation that "organizations have stakeholders."

Unfortunately, much of what passes for stakeholder theory in the literature is implicit rather than explicit, which is one reason why diverse and sometimes confusing uses of the stakeholder concept have not attracted more attention. The stakeholder theory can be, and has been, presented and used in a number of ways that are quite distinct and involve very different methodologies, types of evidence, and criteria of appraisal.(Brenner \& Molander, 1977), It is in light of the aforementioned that the study shall adopt stakeholders theory with a view to interrogate both the independent variable i.e. stakeholders participation and dependent variable , national budget oversight in Kenya ..

\subsection{Empirical Literature}

\subsubsection{Civil Society Participation}

The growth of budget groups amounts may signal an important shift in public finance practice. In most countries, national budgeting has long been considered the exclusive preserve of the executive. It is only recently that the value of opening budget processes to non-government input has been considered desirable in some countries (Krafchik, 2005). For the majority of developing countries, a set of powerful negative myths continue to constrain the independent budget work of civil society, legislatures and the media. These include: budgets must be formulated in secret or they may upset financial markets; non-government intervention can destroy the integrity of the budget envelope; legislators and civil society have a greater interest in advancing the interests of their constituents as opposed to the interests of the country as a whole and it is the government's mandate to produce the budget internally in a closed process; and it's prerogative for it to be rubberstamped by the legislature (Muok \& Kingiri, 2015).

The growth in the number of organizations engaging in budget issues can be attributed to changes in the international context for CSO work. For many civil society groups, budget work is part of a broader set of activities. Civil society organizations help promote citizen participation in governance, along with government accountability and transparency(Zhang, Zhang, Lee \& Wing, 2012). Most notably, there have been dramatic transformations in governmental systems over the past decade. Many countries have shifted from being closed societies to open ones and are striving to build more democratic and participatory decision-making processes. The goals of this ongoing process extend beyond conducting free elections; open and democratic societies require an informed citizenry, public participation, and governing processes that are transparent.

Moreover, the relationship between civil society and government on budgetary issues is not necessarily confrontational and the work of applied budget groups is compatible with increased public sector budgeting capacity (Wampler \& Avritzer, 2014). Although it will depend on the country context, many budget groups operate effectively as critical allies of the government. Budget groups may strengthen government capacity, for example, by providing training, undertaking research of interest to government, working with government in forums and building the potential of the legislature. Independence does imply the possibility of criticism where necessary and this can lead to confrontation, especially where other strategies have not proved useful. But, by adjusting the tone and manner of critical engagement and by producing accurate work, most groups are able to maintain a working relationship with the executive (Wampler \& Avritzer, 2014).

Guthrie (2013) argues that civil society organizations (CSOs) interested in almost any issue can be more effective in their work if they understand the formulation of a budget, how it becomes law, how it is implemented, and how the results are evaluated. Because of its wide-ranging reach and impact, the budget process should be subject to the influence, analysis, and scrutiny of an active and informed civil society (Tax, 2009). Combining an in-depth knowledge of a policy issue, such as health or education, with a solid knowledge of budgets and an effective advocacy strategy has proved to be an outstanding method of influencing policy decisions. Strengthening civil society's ability to analyze budgets and participate effectively can play an integral role not only in policies but also in constructing a more open and participatory democratic society.

Muhuri (2009) assesses the challenges faced by CSOs arguing that the ability of civil society to participate in the budget discussion can be thwarted by legal, institutional, and political barriers. This, combined with the general lack of information on budget issues-and the shortage of information and analysis in widely usable forms using accessible language- has seriously hindered the efforts of national and local organizations attempting to participate in the debate on the use of public resources. CSOs can work to address these deficiencies in budget information and the budget process and thus improve the structure of their government's decision making. By engaging in the budget process from formulation through implementation and audit, CSOs can contribute critical information on the public's needs and priorities that can lead to stronger policy choices ((Zhang, Zhang, Lee \& Wing, 2012). They can also draw more people into the debate by collecting, summarizing into easily understandable formats, and spreading budget information in addition to training members of the public to understand and analyze government budgets themselves. CSOs participation in the budget process can supplement government's capacity to budget effectively by providing technical support and giving an independent opinion on budget proposals and implementation. (NTA, 2013). 


\subsubsection{Funding Agencies Participation}

It is generally agreed, that there are not enough resources to address all the needs of society. Yet. there are pressures on all governments by their citizens, to provide quality goods and services. Many governments, especially those in the developing world, do not have access to enough resources to enable them to do what is expected and required of them, by their citizens (Rios, Bastida \& Benito, 2016). The budget process itself is not divided cleanly into four stages. In practice, the stages overlap. Similarly, the work of budget groups usually spans across more than one stage. Indeed, one of the constant success factors associated with groups around the world is that budget work requires full time commitment. Budget groups must concentrate on all stages in the budget process to be successful.

Donors have in various instances positively influenced the implementation of projects by participating in several budget processes. For instance, they can promote individual citizen participation by supporting capacity development; by facilitating changes in attitudes among the citizens. (Wamugu \& Ogollah, 2017) Donors can also assist by emphasizing inclusiveness at the inclusiveness in the budget cycle and helping to find ways of reaching out to the most vulnerable. Supporting citizen participation and state accountability mechanisms simultaneously- "working both sides of the equation" - through a combination of approaches (e.g. formal political channels and informal ones) can be doubly effective (Ríos, Benito \& Bastida, 2017). The role of donors as political actors has been extensively debated. Supporting stakeholder participation can. at times, he politically sensitive. The "working on both sides of the equation" approach avoids donors being seen as undermining government structures through parallel/independent support to civil society. Tax (2009) additionally argues that it makes particular sense for donors to support the strengthening of local government budget accountability procedures and at the same time support other actors to take advantage of these. This also allows donors to actively support the development of closer understanding and complementary working relations between local government and CSOs where this is feasible.

In Mongolia, for example, although the IMF program refers to fiscal accountability and transparency, no explicit statements, benchmarks or conditionality regarding public access to budget information or public participation in the budget process is contained in their program documents (Bulag, 2018). In the Kyrgyz Republic, while an increase in budget transparency was included in the World Bank's Policy Matrix, little effort went into checking whether this condition had been met in practice. Moreover, a lack of donor coordination limited the leverage that donors had in pushing government to improve transparency (Karimsakov \& Karadag, 2017). In Uganda, on the other hand, conditions linked to the World Bank's Poverty Reduction Support Credit (PRSC) required public service delivery to be monitored through performance and expenditure tracking. A few policies on citizen participatory mechanisms were also approved as part of the PRSC process. In Nicaragua, the latest agreement with the IMF included provisions that address transparency. The publication of external official cooperation flows was added as a new structural benchmark. In order to meet this requirement, Nicaragua's central bank produced two reports of Official External Aid for 2007 and 2008, which were available for a limited time only on the central bank's website (Thaler, 2017).

In summary, evidence about the use of conditionalities and the characteristics of aid delivery may help explain the mixed record of donor technical assistance in improving budget transparency in aid-dependent countries. As we have seen above, conditionalities have been used inconsistently to promote better budget transparency and oversight, and various characteristics of aid, such as fragmentation, lack of transparency and the limited use of program modalities, may have in fact hindered progress in overall budget transparency. Yet, the picture is still not complete, as there is a number of other factors that may have interacted with donor engagement to generate the budget transparency scores The review carried out above clearly shows that the influence of stakeholder participation on the national budget process has not been exhaustive enough. It is therefore this gap that the current study seeks to fill with the hope that the views will be incorporated in the national budgeting process to ensure the process is more beneficial to both the government and the citizens in Kenya.

\subsection{Conceptual Framework}

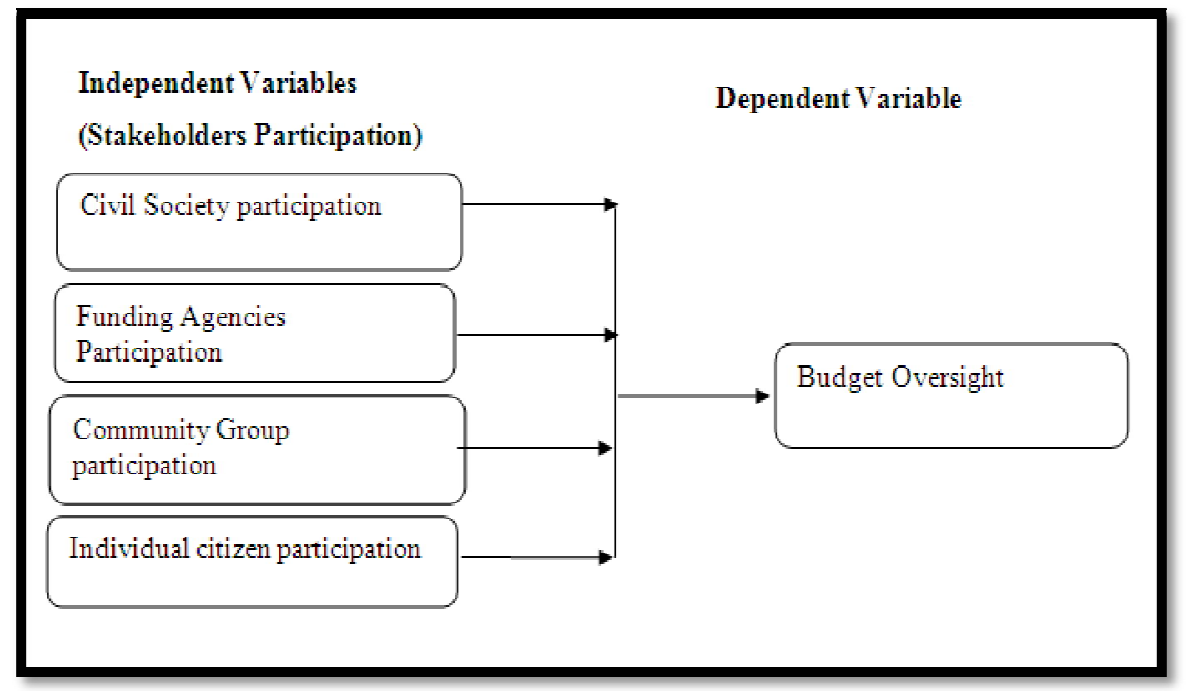

Figure 1: Conceptual Framework 
Shown in figure 1 is a diagrammatic network of independent variables as role of stakeholders, and dependent variable as shown by the arrows above. Level of participation, proportion of participation and involvement mechanisms may lead to either desirable outcome or undesirable outcome to the dependent variable which is the successful fair budgeting depending on the effectiveness or ineffectiveness of participation of the stakeholders.

Effective participation or involvement of stakeholders may result to desirable outcome, that is, successful completion of budgets within the given timelines, of the right quality, transparent management, good relationship with partners and consequent achievement of specific goals. Ineffective involvement and lack of participation by stakeholders may result to undesirable outcome, that is, incomplete infrastructural projects, misappropriation of public funds, failure to meet educational goals and untimely delivery of essential goals.

\subsection{Research Gaps}

Studies done in Kenya on the influence of stakeholders' participation includeNyandika, O. F \& Ngugi, K. (2014). Did a study on influence of stakeholder's participation on? performance of road projects at Kenya national highways. Kioko Stella Maris Mukethe2015 carried out a research on influence of stakeholder involvement in curriculum implementation on pupils' performance in Kenya of primary education in kathiani sub-county, Juliana Mulaa Narmada 2014 studied Management Participation and firm Performance, Firms in Export Processing Zones (EPZs) in Kenya. From the reviewed literature it is evident that there is hardly any empirical research on the influence of stakeholder participation on national budget oversight in Kenya. The research paper is nascent and it is imperative to breach the gap.

\section{Research Methodology}

\subsection{Introduction}

This section describes the methodology that will be used in undertaking the study. It starts by explaining the research design that will be adopted; according to Sekaran (2010) a central part of research is to develop an efficient research strategy. Based on the model and variables developed in section two, this section covers the research design and research methodology used to test the variables. In particular, issues related to research design, the population, the type of data to be collected, sampling frame, sample and sampling techniques, data collection instrument, data collection procedure, pilot test, validity and reliability of the instrument, and the data analysis and presentation are discussed. Lastly, the analytic techniques that will be used to test the hypotheses are also presented. Data will be collected using standardized questionnaire.

\subsection{Research Design}

A descriptive survey design will be used in this study. Survey design collects data on various variables as found in the school system and deal with incidents and relationships According to Kothari (2005), descriptive design describes the Present status of a phenomenon, determining the nature of the prevailing conditions, practices, attitudes and seeking accurate descriptions. Descriptive survey designs are used in preliminary and exploratory studies as cited in Orodho, (2013) to allow researchers to gather information, summarize, present and interpret for the purpose of clarification. A descriptive survey design allows researchers to gather information, summarize, present and interpret it for the purpose of clarification. The method is appropriate since it will allows for collection of qualitative information such as those aimed at measuring attitudes, opinions or habits which this study is aimed at (Mugenda and Mugenda, 2003). The design is therefore, effective for the study as it will be used the researcher to determine the present nature of stakeholder involvement and constraints in budget oversight.

\subsection{Population}

The population of a study can be defined as the total number items, entities or individuals that are being studied by a researcher in a research study. Kothari (2006) defines it as "a specific set of individuals, cases or objects that have some common observable characteristics that are distinct from any other population". This will therefore considered to be the entire population that will be the focal point of the study and this means that the data that will be analysed in the study will be collected from either the entire group or from some of the members of this group. The target population has also been defined by other researchers such as Stevvatt and Kamins (2010) who define it as the population from which data will be collected from for the study and the results will be generalized to it. It is important to clearly describe the target population for a study since this makes it easy for the researcher to collect the right data and in the appropriate place and time. 


\begin{tabular}{|c|c|}
\hline Institutions & Population Size/ Number \\
\hline Civil society organizations & 10 \\
\hline The office of auditor general & 15 \\
\hline Private / public universities & 63 \\
\hline Kenya national library & 17 \\
\hline The National treasury & 23 \\
\hline Parliament & 32 \\
\hline Funding agencies & 16 \\
\hline Central Bank/ Service Providers & 9 \\
\hline Counties Reps & 47 \\
\hline County employees & 68 \\
\hline
\end{tabular}

Table 1: Distribution of Stakeholder's Population Size in Kenya

Source: Researcher 2018

\subsubsection{Sample Frame}

Sampling frame is a list of elements from which the sample is actually drawn and closely related to the population. (Cooper, 2006). The sample frame drawn from respondents including those From Civil society organizations, The office of auditor general, Procurement, Personnel, transport, ICT support and library The treasury, the central bank and ICT Consortium .Counties Reps Kenya national library The National treasury Parliament Funding agencies Central Bank/ Service Providers Public Universities

\subsubsection{Sample Design}

Sampling is a process or technique of selecting a suitable sample or a representative part of the population for the purposes of determining parameters or characteristics of the whole population, (Kothari.1990).

The study used stratified sampling, Purposive Sampling and Random Sampling Techniques. Stratified sampling will be used to identify the necessary study population a stratified sampling technique is used to identify sub-groups in the population and their proportions and select from the sub-groups the respondents to form sample size. Purposive sampling was used to identify study units. Stratified sampling used to ensure that the target population is divided into different strata and each stratum is represented in the sample stratified random sampling used for support county employees and public universities The advantage of this method is that it increases statistical efficiency and provide data for analysis of the various sub-populations, ( Cooper and Schindler, 2006

\subsection{Data Collection}

For purposes of this study, primary data was obtained through a questionnaire structured to meet the objectives of the study. The questionnaires was used because they are straightforward and less time consuming for both the researcher and the participants (Flick, 2017). The questionnaires had a number of sub-sections that were sub-divided based on the major research questions except the first sub-section (section A) that meant to capture the background information of the participants like gender, marital status, age, working experience, level of education. Other sections will address questions to achieve each of the specific objectives of the study.

The questions were both open - ended and closed ended. The closed ended questions helped capture the results that quantified the analysis. The open ended questions helped in eliciting responses that qualitatively analyzed and helped capture the issues that are relevant to the study but could not be captured by structured questions. The researcher administered the questionnaires to ensure the accuracy of the responses from citizens. Oral interviews with the various members of interest groups will also be conducted by the researcher

\subsection{Reliability and Validity}

To establish the validity of the research instruments the researcher sought opinions of experts in the field of study especially the lecturers in the School of Business. This facilitated the necessary revision and modification of the research instrument thereby enhancing validity. Mugenda and Mugenda (2003) contend that the usual procedure in assessing the content validity of a measure is to use a professional or expert in a particular field.

According to Noble and Smith (2015), reliability refers to the consistency of measurement and is frequently assessed using the test-retest reliability method. The questionnaires will be tested for reliability using the Cronbach reliability test where the alpha coefficients were measured. Reliability increased by including many similar items on a measure, by testing a diverse sample of individuals and by using uniform testing procedures

\subsection{Data Analysis}

After collection of data and testing for reliability, the questionnaires were coded and analyzed with the aid of the Statistical Package for Social Sciences (SPSS). Thereafter, the study used descriptive statistics and inferential statistics to establish the role of stakeholder participation on the national budget oversight. The descriptive statistics here will make use of percentages. The data will be presented in the form of tables and pie charts. 


\section{Analysis, Findings and Presentation}

\subsection{Introduction}

Data was analyzed, interpreted and presented in graphs and tables preceding each specific objective. From the findings, discussions generated objectively and deduced conclusions and recommendations. This chapter describes the respondents 'demographics and characteristics while the preceding chapter's deals with presentation and interpretation of research findings based on each research objective.

\subsection{Data Analysis/ Presentation}

Analysis of data is a process of inspecting, cleaning, transforming and modeling of data with an aim of highlighting useful information, suggesting conclusions and supporting decision making. According Adler (2008), data analysis has multiple facets and approaches, encompassing diverse techniques under a variety of names, indifferent business science and social science domains. This section presents the findings from questionnaires administered among171 respondents both male and female above 18 years from. The findings were presented as per the variables that were of interest to the study.

\subsection{Response Rate}

The study sampled 171 respondents out of which 171 filled and returned the questionnaires making the response rate of $100 \%$. The response rate was satisfactory to make conclusions on therole of stakeholder participation on the national budget oversight in Kenya. According to Mugenda and Mugenda (2003), a response rate of 50\% is adequate for analysis and reporting a rate of $60 \%$ is good and a response rate of $70 \%$ and over is excellent. Based on the assertion, the response rate was considered excellent.

\subsection{Reliability Analysis}

The pilot study was to determine reliability of the questionnaires. Reliability of the questionnaire was evaluated through Cronbach's Alpha which measures the internal consistency and establishes if items within a scale measure the same constructs. SPSS was adopted quantitatively and index alpha was computed to measure the average of measurable items and its correlation. The Cronbach's Alpha was established for every variable which formed the scale as shown on table 2

\begin{tabular}{|c|c|c|}
\hline Variable & Cronbach's Alpha & Number of items \\
\hline Civil society organizations & 0.803 & 10 \\
\hline The office of auditor general & 0.810 & 10 \\
\hline ICT council & 0.803 & 10 \\
\hline Community organizations & 0.786 & 10 \\
\hline The National treasury & 0.802 & 10 \\
\hline Parliament & 0.756 & 10 \\
\hline Funding agencies & 0.730 & 10 \\
\hline County reps & 0.786 & 10 \\
\hline Central Bank/ Service Providers & 0.789 & 10 \\
\hline Private / Public Universities & 0.704 & 10 \\
\hline County employees & 0.783 & \\
\hline
\end{tabular}

Table 2: Reliability Analysis

The table 2 shows that the office of auditor general had the highest reliability $(\alpha=0.810)$ followed by ICT Section $(\alpha 0.803)$, CSOs $(\alpha 0.803)$ The National Treasury $(\alpha 0.0 .802)$ and rest above $(0.700)$. This illustrates that all the variables were reliable as their reliability values exceeded the prescribed threshold of 0.700 as contended by Geld (2009). The results of the reliability test also revealed that the variables were reliable as the average index of 0.800 which exceeded the adopted threshold of 0.700 .

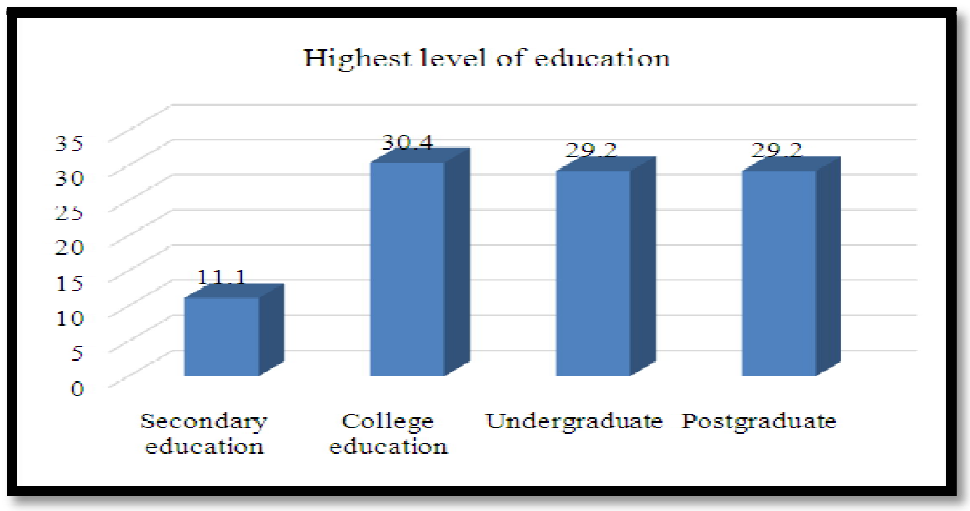

Figure 2: High Level of Education 
The study sought to find out respondents level of education. From the findings, majority of the respondents 30.4 $\%$ have college education, $29.2 \%$ have undergraduate education (degree) $29.2 \%$ have post graduate qualifications and only $11.1 \%$ had secondary certificate. Thus the respondents had the basic knowledge to understand and respond to questions.

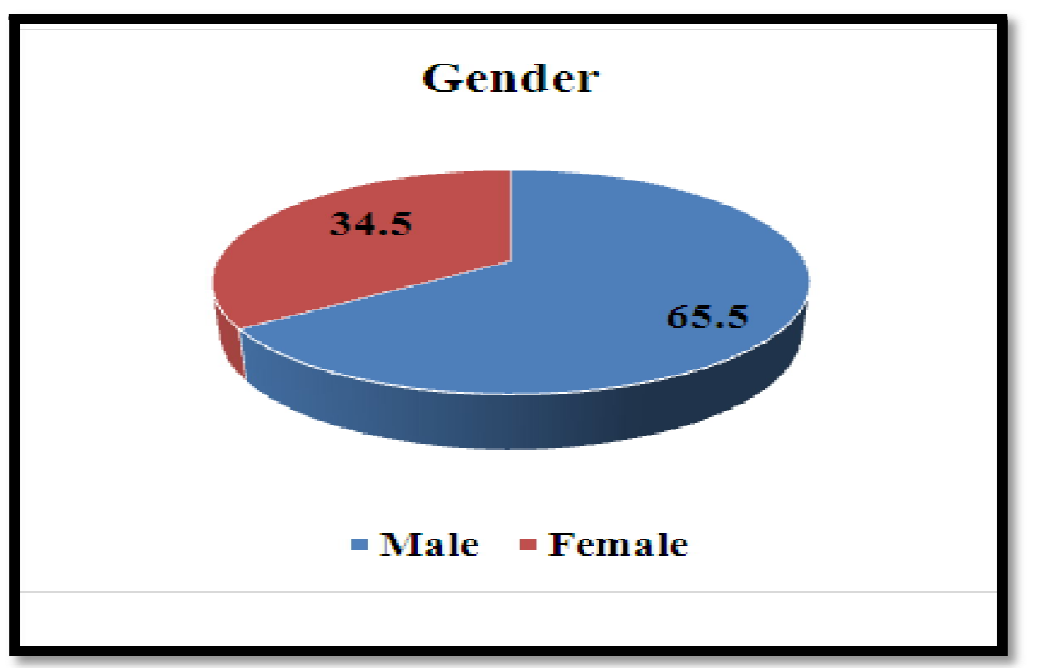

Figure 3: Gender

With regard to respondent's gender, the study found out that $65.5 \%$ of the respondents were male while $34.5 \%$ of the respondents were female. This shows that the study did not suffer from gender bias since both genders were fairly included in the study.

\subsection{Age Bracket}

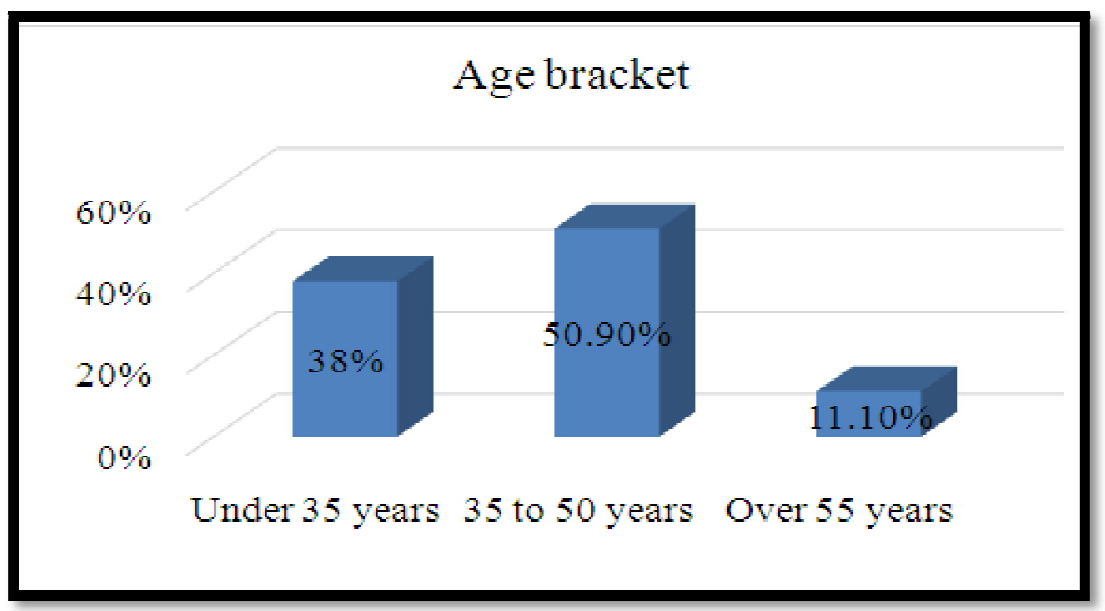

Figure 4: Age Bracket

The study requested the respondents to indicate their age. From the findings $50.9 \%$ of the respondents indicated between 35-50 years.38\% indicated that were under 35 years and11.10\% indicated over 50years. This is a fair representation of age cohort's diversity in stakeholder participation

\section{Role of Stakeholder Participation on national Budget Oversight}

Influence of Stakeholder participation on national budget oversight in Kenya. To what extent would you say each of the following factors have influenced national budget oversight in Kenya Where; 1 not at all, $2=\mathrm{a}$ little bit, $3=$ moderately, $4=$ great extent and $5=$ very great extent. 


\begin{tabular}{|c|c|c|c|c|c|c|c|c|}
\hline Factors & $\begin{array}{c}\text { Not } \\
\text { at all }\end{array}$ & $\begin{array}{c}\mathbf{A} \\
\text { little } \\
\text { bit }\end{array}$ & Moderately & $\begin{array}{c}\text { Great } \\
\text { extent }\end{array}$ & $\begin{array}{c}\text { Very } \\
\text { great } \\
\text { extent }\end{array}$ & Mean & $\begin{array}{c}\text { Std. } \\
\text { Deviation }\end{array}$ & Variance \\
\hline County Reps & & 5 & 31 & 70 & 65 & 4.14 & 0.663 & 0.844 \\
\hline Civil society organizations & 26 & 6 & 55 & 50 & 34 & 3.35 & 1.344 & 1.617 \\
\hline The office of auditor general & 31 & 12 & 55 & 38 & 35 & 3.2 & 1.344 & 1.807 \\
\hline ICT council & 39 & 23 & 48 & 30 & 31 & 2.95 & 1.399 & 1.956 \\
\hline Community organizations & 14 & 31 & 46 & 33 & 41 & 3.34 & 1.271 & 1.616 \\
\hline The National treasury & 8 & 5 & 21 & 23 & 114 & 4.35 & 1.103 & 1.216 \\
\hline Parliament & 8 & 8 & 18 & 44 & 93 & 4.2 & 1.106 & 1.223 \\
\hline Funding agencies & 5 & 3 & 40 & 45 & 78 & 4.1 & 1.01 & 1.019 \\
\hline Central Bank/ Service Providers & 6 & 8 & 25 & & 66 & 4.04 & 1.02 & 1.039 \\
\hline Public Universities & 16 & 5 & 19 & & 97 & 4.12 & 1.278 & 1.633 \\
\hline Individual / citizen participation & 13 & 10 & 27 & 34 & 87 & 4.01 & 1.263 & 1.594 \\
\hline
\end{tabular}

Table 3

\subsection{National Budget Oversight and Performance}

On issues relating to the role of stakeholder participation on national budget oversight in Kenya. The ICT Council was at the top in representation and involvement in the process of budgeting process hence all transactions are done within the operations and provisions of e commerce and e economics ,further The office of auditor general depicted an increased SD of 1.344 as was the case of National treasury with a similar SD of 1.344, this is an indication that both the institutions are very key to all issues relating to budgetary oversight nationally. It could be deduced that without these two constitutional offices being involved in National Budget Directly, oversight may not sufficiently and effectively undertaken. The civil society takes prominence among others due to its premise of lobbying advocacy and activism. The civil society is able with aid of donor and other foreign funding agencies to put together repute institutions and interrogate the presentation and appropriation of the national budget. This process involves scrutiny of itemized government spending and revenues allocations / expenditure with a view to expolate on any misuse and or abuse of public funds.

5.2. To What Extent Would You Say Stakeholder Participation Has Been of Benefit to National Budget Oversight in Kenya? Where; $1=$ not at all, $2=$ a little bit, $3=$ moderately, $4=$ great extent and $5=$ very great extent.

\begin{tabular}{|c|c|c|c|c|c|c|c|c|}
\hline & $\begin{array}{c}\text { Not } \\
\text { at } \\
\text { all }\end{array}$ & $\begin{array}{c}\text { A } \\
\text { little } \\
\text { bit }\end{array}$ & Moderately & $\begin{array}{c}\text { Great } \\
\text { extent }\end{array}$ & $\begin{array}{c}\text { Very } \\
\text { great } \\
\text { extent }\end{array}$ & Mean & $\begin{array}{c}\text { Std. } \\
\text { Deviation }\end{array}$ & Variance \\
\hline $\begin{array}{c}\text { Stakeholder participation } \\
\text { systems allows the national } \\
\text { budget oversight to realize } \\
\text { global reach }\end{array}$ & & 11 & 21 & 45 & 94 & 4.3 & 0.92 & 0.846 \\
\hline $\begin{array}{c}\text { capital funding influences } \\
\text { National budget oversight }\end{array}$ & 20 & 13 & 34 & 44 & 60 & 3.65 & 1.339 & 1.794 \\
\hline $\begin{array}{c}\text { Stakeholders participation } \\
\text { influences budget planning } \\
\text { processes }\end{array}$ & 5 & 16 & 23 & 54 & 73 & 4.02 & 1.098 & 1.206 \\
\hline $\begin{array}{c}\text { Citizen participation allows for } \\
\text { proper utilization of national } \\
\text { resources }\end{array}$ & 26 & 19 & 37 & 31 & 58 & 3.44 & 1.439 & 2.072 \\
\hline $\begin{array}{c}\text { Stakeholder participation allows } \\
\text { equity and equality I National } \\
\text { budget oversight for efficiency, } \\
\text { reliability and smooth flow of } \\
\text { operations. }\end{array}$ & 10 & 14 & 24 & 46 & 77 & 3.97 & 1.205 & 1.452 \\
\hline $\begin{array}{c}\text { Office of the Auditor general } \\
\text { enable processing of large } \\
\text { volumes and sizes of } \\
\text { transactions in an efficient / } \\
\text { timely/ secure system }\end{array}$ & 3 & 13 & 16 & 56 & 83 & 4.19 & 1.006 & 1.012 \\
\hline
\end{tabular}

Table 4 


\subsubsection{Stakeholder Participation Allows National Budget Oversight to Realize Global Reach}

When asked a question on whether stakeholder participation allows the National budget oversight to realize global reach, the study recorded a mean of 4.3 and standard deviation of 0.920 . This is indications that indeed to a very great extend stakeholder participation influences the National budget oversight to realize its global reach. In the foregoing, it was established that progress has been made in automating government payment systems and financial services systems in general. Capital funding influences National budget oversight to a great extent. This is highly depicted with a SD of 1.339, deducing that National budget oversight is a process that must also be budgeted for hence the importance of seeking for funding in order to facilitate the processes to its logical end. Citizen participation allows for perceived proper utilization of national resources even then, whereas citizens take a very active and robust enthusiasm in national budget oversight, it is argued that the public participation could only be a constitutional requirement and may result into little or not outcomes at all in relation to National Budget oversight outcomes

\section{Summary Conclusions and Recommendations}

\subsection{Introduction}

The summary conclusions and recommendations are presented in line with the respective research objectives. Conclusions are based on the study analysis conducted in the previous chapters the recommendations are made with regards to the conclusions reached after the data was analyzed.

\subsection{Summary}

Role of stake holder participation on budget oversight in Kenya ,this was investigated in terms of National Budget Oversight and performance and stakeholder participation benefit to national budget oversight in Kenya .The study further analyzed National budget oversight to realize its global reach .Capital funding influenceon National budget oversight. and Citizen participation perceived proper utilization of national resources. Kenya.

\subsection{Conclusion}

With regards to stakeholder participation $100 \%$ was witnessed to have taken part in the national budget oversight processes. This actually shows that the stakeholders have taken their oversight role with great precision and seriousness. With this it is presumed that public funds shall be properly utilized for the correct purpose intended effectiveness and efficiency the study concluded that Budget processes and outcomes are manifestation of stakeholder's participation in proper performance of the national budget oversight. Citizen participation to a great extend influence the level of encounter with national budget oversight in Kenya However it was argued that the citizens lack feedback / followup modalities from where they could be able to fathom their oversight role, thus could the national Budget oversight process warranty the term oversight or simply rubberstamp?:(Respondent retorted ) thence it is conclusive that the stakeholders participation may not after all influence national budget oversight due to lack of feedback and or communication thereof.

The study concluded that Capital funding influences National budget oversight to a great extent this is highly crucial in supporting and enhancing oversight processes' thus the government to provide sufficient funding $g$, and also the office of the Auditor general to link with other well-wishers, donors and funding agencies to build sufficient capital requisition base from the national treasury in order to widen capacity building stakeholder participation leverage and oversight roles with the view to achieve proper and efficient utilization of public funds .

\subsection{Recommendations}

The study recommended on the need to explicitly address both human and technical issues in terms of feedback and manifest outcomes the study recommend that to mitigate challenges facing stakeholder's participation on National budget oversight, there is need for the stakeholders to participate in contributions of ideas from the onset of budget initiation, making up to the oversight ant approval stage thus stakeholder budget oversight hands on

\section{References}

i. Andriof, J., Waddock, S., Husted, B., \& Rahman, S. S. (2017). Jensen's approach to stakeholder theory. In Unfolding Stakeholder Thinking (pp. 85-100). Routledge.

ii. Box, R. C. (2015). Democracy and public administration. Routledge.

iii. Bulag, U. E. (2018). Mongolia in 2017: A Year of Feudal Fights in a Democracy. Asian Survey, 58(1), 80-85.

iv. Csikszentmihalyi, M., \& Larson, R. (2014). Validity and reliability of the experience-sampling method. In Flow and the foundations of positive psychology (pp. 35-54). Springer Netherlands.

v. Erba, J., Ternes, B., Bobkowski, P., Logan, T., \& Liu, Y. (2018). Sampling Methods and Sample Populations in Quantitative Mass Communication Research Studies: A 15-Year Census of Six Journals. Communication Research Reports, 35(1), 42-47.

vi. Finch, C. (2015). Participation in Kenya's Local Development Funds.

vii. Finch, C., \& Omolo, A. (2015). Building Public Participation in Kenya's Devolved Government.

viii. Flick, U. (Ed.). (2017). The SAGE Handbook of Qualitative Data Collection. SAGE.

ix. Freeman, R. E., Harrison, J. S., Wicks, A. C., Parmar, B. L., \& De Colle, S. (2010). Stakeholder theory: The state of the art. Cambridge University Press.

x. Freeman, R.E. (1984). Strategic Management. A Stakeholder Approach. Marshfield, MA: Pitman 
xi. Guthrie, D. M. (2013). Engaged Governance: An Institutional Approach to Government Community Engagement , A Background Paper. Prepared for and presented at the United Nations Department of Economic and Social Affairs Interregional Workshop on "Engaged Governance". Colombo, Sri Lanka. December 9-11, 2003

xii. Karimsakov, K., \& Karadag, M. (2017). A Social Accounting Matrix For Kyrgyzstan For 2010.Ege Akademik Bakis, 17(1), 23.

xiii. Kenya 2017/ 2018 budget report. Retrieved from http://www.treasury.go.ke/ component/jdownloads/ send/ 175budget-statement/ 518-budget-statement-2017-18.html?option=com_jdownload

xiv. Kim, J., Ko, E. Y., Jung, J., Lee, C. W., Kim, N. W., \& Kim, J. (2015, April). Factful: Engaging taxpayers in the public discussion of a government budget. In Proceedings of the 33rd Annual ACM Conference on Human Factors in Computing Systems (pp. 2843-2852). ACM.

xv. Kothari, C. R. (2006). Research Methodology: Methods and Techniques. Cengage Learning, London

xvi. Krafchik, W. (2005). Can civil society add value to budget decision-making? A description of the rise of civil society budget work. Citizen Participation and Pro-Poor Budgeting, 57.

xvii. Mugenda, O.M \& Mugenda, A. G (2003) Research Methods: Qualitative and Qualitative Approaches, Acts Press, Nairobi

xviii. Muok, B. O., \& Kingiri, A. (2015). The role of civil society organizations in low-carbon innovation in Kenya. Innovation and Development, 5(2), 207-223.

xix. Nabatchi, T., Ertinger, E., \& Leighninger, M. (2015). The future of public participation: Better design, better laws, better systems. Conflict Resolution Quarterly, 33(S1).

xx. Noble, H., \& Smith, J. (2015). Issues of validity and reliability in qualitative research. Evidence-Based Nursing, ebnurs-2015.

xxi. Omolo, A. (2015). Practical Approaches for County Governments to Facilitate Public Participation in the Planning and Budget Process.

xxii. Purvis, R. L., Zagenczyk, T. J., \& McCray, G. E. (2015). What's in it for me? Using expectancy theory and climate to explain stakeholder participation, its direction and intensity. International Journal of Project Management, 33(1), 314.

xxiii. Ríos, A. M., Bastida, F., \& Benito, B. (2016). Budget transparency and legislative budgetary oversight: An international approach. The American Review of Public Administration, 46(5), 546-568.

xxiv. Ríos, A. M., Benito, B., \& Bastida, F. (2017). Factors explaining public participation in the central government budget process. Australian Journal of Public Administration, 76(1), 48-64.

xxv. Sierra-García, L., Zorio-Grima, A., \& García-Benau, M. A. (2015). Stakeholder engagement, corporate social responsibility and integrated reporting: an exploratory study. Corporate Social Responsibility and Environmental Management, 22(5), 286-304.

xxvi. Stewatt. D. W and Kamins M.A (2010). Secondary data research method. Traditional Chinese ed., Newbury Park California Sage.

xxvii. Tax, A. (2009). Tax Expenditure. Economic Survey, 10.

xxviii. Thaler, K. M. (2017). Nicaragua: A Return to Caudillismo. Journal of Democracy, 28(2), 157-169.

xxix. Tsofa, B., Molyneux, S., Gilson, L., \& Goodman, C. (2017). How does decentralisation affect health sector planning and financial management? a case study of early effects of devolution in Kilifi County, Kenya. International journal for equity in health, 16(1), 151.

xxx. Wampler, B. and Avritzer, L. (2014) Participatory Publics: Civil Society and New Institutions in Democratic Brazil. Comparative Politics. Forthcoming

xxxi. Wamugu, J. W., \& Ogollah, K. (2017). Role of stakeholders participation on the performance of constituency development fund projects in Mathira East constituency in Kenya. International Academic Journal of Information Sciences and Project Management, 2(1), 104-125.

xxxii. Willmott, K. (2017). Taxpayer governmentality: governing government in Metro Vancouver's transit tax debate. Economy and Society, 46(2), 255-274.

xxxiii. Woolum, J. ( 2011). Citizen Involvement in Performance Measurement and Reporting. Public Performance and Management Review, 35: 79-112

xxxiv. Yang, K. and S. K. Pandey (2011). "Further Dissecting the Black Box of Citizen Participation: When Does Citizen Involvement Lead to Good Outcomes?" Public Administration Review 71(6): 880-892.

xxxv. Zhang, Y., Zhang, Y., Lee, R., \& Yang, K. (2012). Knowledge and skills for policy making: Stories from local public managers in Florida. Journal of Public Affairs Education, 183-208. 


\section{Appendix}

\section{Questionnaire}

The study is on the role of stakeholders on national budget oversight. Put a tick against the appropriate choice. Fill the date in the spaces provided below each question. In case of any additional information, you can attach a written statement.

Section A: Bio Data of the Respondent.

1. Gender
a) Male [ ]
b) Female [ ]

2. What is your highest qualification?
a) Diploma
[ ]
b) Bachelor's Degree [ ]
c) Masters
d) $\mathrm{PhD}$

3. Which institution do you work for?
a) Controller of Budget
b) Auditor General
c) Salaries and Remuneration Commission [ ]
d) Central Bank of Kenya
e) Commission on revenue allocation

4. What position do you hold in your institution?

5. How long have you worked in your current institution?
a) Below 3 years
b) Between 3-5 years
[ ]
c) Above 5 years
[]

Section B: Role of Stakeholders on Budget Oversight

Please indicate the extent to which you agree with the following statement relating to the role of civil society organizations on budget oversight where 1=Strongly Disagree (SD), 2= Disagree (D) 3= Neutral (N), 4= Agree(A), 5= Strongly Agree (SA)

\begin{tabular}{|c|c|c|c|c|c|}
\hline Statement & $\begin{array}{c}\text { Strongly } \\
\text { Disagree (SD) }\end{array}$ & $\begin{array}{c}\text { Disagree } \\
\text { (D) }\end{array}$ & Neutral (N) & Agree (A) & $\begin{array}{c}\text { Strongly } \\
\text { Agree (SA) }\end{array}$ \\
\cline { 2 - 5 } $\begin{array}{c}\text { Civil society is an intrinsic part of the } \\
\text { state }\end{array}$ & 1 & 2 & 3 & 4 & 5 \\
\hline $\begin{array}{c}\text { Civil society budget groups are often } \\
\text { able to be in close, regular contact } \\
\text { with citizens and interest groups. }\end{array}$ & & & & & \\
\hline $\begin{array}{c}\text { Many civil society organizations } \\
\text { develop budget training expertise } \\
\text { resulting in stronger interventions } \\
\text { and oversight. }\end{array}$ & & & & & \\
\hline $\begin{array}{c}\text { Develop budget literacy and debate } \\
\text { among citizens, interest groups and } \\
\text { legislators }\end{array}$ & & & & & \\
\hline $\begin{array}{c}\text { Promotes and guides decisions made } \\
\text { on the budget forum }\end{array}$ & & & & & \\
\hline $\begin{array}{c}\text { Collate, synthesize and disseminate } \\
\text { budget information to the citizens }\end{array}$ & & & & & \\
\hline $\begin{array}{c}\text { Civil society organizations provide } \\
\text { Independent critical analysis of the } \\
\text { budget }\end{array}$ & & & & & \\
\hline $\begin{array}{c}\text { Civil society budget groups bring } \\
\text { new information to budget decision- } \\
\text { making }\end{array}$ & & & & & \\
\hline $\begin{array}{c}\text { Civil society organizations assist } \\
\text { citizens and the legislature to } \\
\text { reinforce channels of accountability }\end{array}$ & & & & & \\
\hline
\end{tabular}




\begin{tabular}{|c|c|c|c|c|c|}
\hline Statement & $\begin{array}{c}\text { Strongly } \\
\text { Disagree (SD) }\end{array}$ & $\begin{array}{c}\text { Disagree } \\
\text { (D) }\end{array}$ & Neutral (N) & Agree (A) & $\begin{array}{c}\text { Strongly } \\
\text { Agree (SA) }\end{array}$ \\
\cline { 2 - 6 } & 1 & 2 & 3 & 4 & 5 \\
\hline $\begin{array}{c}\text { Evaluate the replicability and } \\
\text { sustainability of the budget }\end{array}$ & & & & & \\
\hline $\begin{array}{c}\text { Increase interaction and } \\
\text { communication between citizens } \\
\text { and the government }\end{array}$ & & & & & \\
\hline $\begin{array}{c}\text { Ensure cooperation and } \\
\text { coordination among federal, state, } \\
\text { tribal, and local government } \\
\text { agencies }\end{array}$ & & & & & \\
\hline $\begin{array}{c}\text { Bring pro-poor perspective to } \\
\text { budget deliberations }\end{array}$ & & & & & \\
\hline
\end{tabular}

Table 5

Section C: Challenges to Stakeholder Participation on National Budget Oversight

Please indicate the extent to which you agree with the following statement relating the role of civil society organizations on budget oversight where $1=$ Strongly Disagree (SD), $2=$ Disagree (D) $3=$ Neutral (N), $4=$ Agree (A), $5=$ Strongly Agree (SA)

\begin{tabular}{|c|c|c|c|c|c|}
\hline Statement & $\begin{array}{c}\text { Strongly } \\
\text { Disagree (SD) }\end{array}$ & $\begin{array}{c}\text { Disagree } \\
\text { (D) }\end{array}$ & $\begin{array}{c}\text { Neutral } \\
\text { (N) }\end{array}$ & Agree (A) & $\begin{array}{c}\text { Strongly } \\
\text { Agree (SA) }\end{array}$ \\
\hline $\begin{array}{c}\text { Donors are accountable to themselves, } \\
\text { through self-regulation, and to } \\
\text { external actors, including non- } \\
\text { operational agencies, host } \\
\text { governments, taxpayers and the } \\
\text { media }\end{array}$ & 1 & 2 & 3 & 4 & 5 \\
\hline $\begin{array}{c}\text { Donors use modalities such as budget } \\
\text { support and pooled sector funds }\end{array}$ & & & & & \\
\hline $\begin{array}{c}\text { Pool resources together and promote } \\
\text { joint funding }\end{array}$ & & & & & \\
\hline $\begin{array}{c}\text { Attract other donors to support } \\
\text { government initiatives and } \\
\text { programmes }\end{array}$ & & & & & \\
\hline $\begin{array}{c}\text { Increase openness on funds available } \\
\text { Sharing information on good practices }\end{array}$ & & & & & \\
\hline $\begin{array}{c}\text { Ensure the country has a national } \\
\text { policy on budget Accuracy }\end{array}$ & & & & & \\
\hline $\begin{array}{c}\text { Setting up institutional arrangements } \\
\text { for the management of funds donated }\end{array}$ & & & & & \\
\hline $\begin{array}{c}\text { Donors interact with the civil society } \\
\text { to ensure budgeting is well conducted }\end{array}$ & & & & & \\
\hline $\begin{array}{c}\text { Promote country leadership in the } \\
\text { formulation of the budget }\end{array}$ & & & & & \\
\hline $\begin{array}{c}\text { Help link budget support objectives } \\
\text { and conditions to national strategies }\end{array}$ & & & & & \\
\hline $\begin{array}{c}\text { Build active policy-dialogue and broad } \\
\text { partnership throughout the lifespan of } \\
\text { budget support programmes }\end{array}$ & & & & & \\
\hline $\begin{array}{c}\text { Funding agencies help link country } \\
\text { allocation of resources to results and } \\
\text { performance }\end{array}$ & & & & & \\
\hline
\end{tabular}

Table 6 